\title{
Incidence of phytoplankton and environmental conditions on the bacterial ammonium uptake in a subtropical coastal lagoon
}

\author{
Germán PÉREZ, ${ }^{1}$ Laura FARÍAS, ${ }^{2}$ Camila FERNANDEZ, $, 3,4$ Daniel CONDE, ${ }^{6}$ Claudia PICCINII ${ }^{*}$ \\ ${ }^{1}$ Departamento de Microbiología, Instituto Investigaciones Biológicas Clemente Estable, Avenida Italia 3318, Montevideo 11600 , \\ Uruguay; ${ }^{2}$ Departamento de Oceanografía, Universidad de Concepción, Casilla 160-C, Concepción, Chile; ${ }^{3}$ Sorbonne Universités, \\ UPMC Univ. Paris 06, UMR 7621, Laboratoire d'Océanographie Microbienne, Observatoire Océanologique, F-66650 Banyuls/mer, \\ France; ${ }^{4}$ CNRS, MR 7621, Laboratoire d'Océanographie Microbienne, Observatoire Océanologique, F-66650 Banyuls/mer, France; \\ ${ }^{5}$ Department of Oceanography and Interdisciplinary center for Aquaculture Research (INCAR), University of Concepción, Chile; \\ ${ }^{6}$ Sección Limnología, Facultad de Ciencias, Universidad de la República, Iguá 4225, Montevideo 11400, Uruguay \\ *Corresponding author: cpiccini@iibce.edu.uy
}

\begin{abstract}
We analyzed the coupling between bacterioplankton and phytoplankton in Laguna de Rocha through an experimental approach. A freshwater zone of high turbidity and macrophytes growth and a brackish zone of higher light penetration and lower macrophytes biomass characterize this coastal lagoon. It has been shown that dissolved inorganic nitrogen, especially $\mathrm{NH}_{4}^{+}$, has decreased to undetectable levels during the last decade. One hypothesis for this trend is the rapid removal by phytoplankton and bacterioplankton uptake. In an attempt to test this, we performed incubations using lagoon water from both zones split in two treatments (pre-filtered by $1.2 \mu m$ and unfiltered water) and amended with ${ }^{15} \mathrm{~N}_{-} \mathrm{NH}_{4}^{+}$. After $4 \mathrm{~h}$ incubation we found that in both zones bacterioplankton showed significantly higher $\mathrm{NH}_{4}^{+}$uptake rates when incubated together with phytoplankton and that uptake rates of both microbial communities were higher in freshwater incubations. These results suggest that bacterial $\mathrm{NH}_{4}^{+}$uptake would be coupled to phytoplankton-derived exudates and hence that depletion of dissolved $\mathrm{NH}_{4}^{+}$in this system could be linked to rapid microbial uptake. The degree of this coupling would vary according to hydrological dynamics in this ecosystem.
\end{abstract}

Key words: ammonium uptake rates, coastal lagoon, microbial interactions.

Received: July 2013. Accepted: September 2013.

\section{INTRODUCTION}

It is well known that phytoplankton and bacterioplankton (including bacteria and archaea) are key components for the functioning of marine and freshwater ecosystems through processes like primary production and remineralization of organic matter (Pomeroy, 1974). It is also known that heterotrophic bacterial production is coupled to primary production (Cole et al., 1988). However, the degree of coupling and the return of dissolved organic carbon to higher trophic levels via the microbial loop have been shown to vary according to the nature of the ecosystem. In open oceans and clear water lakes the flow of energy is controlled by nutrients, being phytoplankton the main energy source for grazers and dissolved organic carbon derived from phytoplankton the main energy source for bacteria, so that bacteria-phytoplankton coupling is tight (Fouilland and Mostajir, 2010). In contrast, in estuaries and coastal lagoons the plankton system might have a net heterotrophic metabolism or show seasonal shifts from net autotrophy to net heterotrophy, which may be due to turbidity, changes in nutrient availability or to inputs of allochthonous organic matter (Revilla et al., 2002; Hopkinson and Smith, 2005). As a consequence, in tran- sitional ecosystems bacteria can meet their organic matter requirements not only via primary production but also through plants leachates, macrophytes exudates or allochthonous sources (i.e., runoff, riverine inputs), which lead to a loose coupling between bacteria and phytoplankton (Parker, 2005).

In any case, the nature of the interactions between phytoplankton and bacterioplankton will be determined by several factors, such as the $\mathrm{C}: \mathrm{N}$ ratio of metabolized substrates (Goldman and Dennet, 2000), availability of light and temperature (Lind et al., 1997), availability of dissolved organic compounds (Björkman and Karl, 1994) and bacterial surface-to-volume ratio (Brock et al., 1994). For example, heterotrophic bacteria can compete with phytoplankton for inorganic nutrients (e.g., ammonium, $\mathrm{NH}_{4}^{+}$, nitrate, $\mathrm{NO}_{3}{ }^{-}$or orthophosphate, $\mathrm{PO}_{4}^{-3}$ ) and indirectly limiting primary production due to nutrient deprivation (Joint et al., 2002). This would provoke a decrease in the amount of dissolved organic matter (DOM) released by phytoplankton and in turn reduce its availability for bacterial growth (Havskum et al., 2003).

Preliminary evidence suggests that the effects of nitrogen addition on algal production and community assem- 
blage may depend on the source and chemical composition of the added nitrogen in freshwater lakes (Berman and Chava 1999; Finlay et al., 2010). In this sense, it has been shown that $\mathrm{NH}_{4}^{+}$addition into phosphorus-rich lakes would favour cyanobacteria, probably owing to their higher uptake kinetics for that compound, whereas $\mathrm{NO}_{3}{ }^{-}$amendments would selectively stimulate the growth of eukaryotic algae, whose nitrate reductase can be induced faster than that of cyanobacteria (Blomqvist et al., 1994). Changes in the primary producers assemblage would, in turn, affect the DOM fluxes and availability for bacterioplankton growth. The relationship between phytoplankton and bacterioplankton strongly depends on the specific characteristics of each aquatic ecosystem and are therefore difficult to predict. Consequently, assessing the nutrient fluxes through these two communities of the microbial loop seems essential to gain insight into the biogeochemical processes occurring in the water column and to understand at which extent the ecosystem functioning may be influenced by these two microbial communities.

Laguna de Rocha is a shallow and productive coastal lagoon on the Atlantic coast of Uruguay that has shown symptoms of eutrophication (Conde et al., 1999; Aubriot et al., 2005). For instance, cyanobacteria and heterotrophic bacterial blooms have been observed, the latter associated to high $\mathrm{NH}_{4}{ }^{+}$concentrations (Piccini et al., 2006). Concomitantly, a regular decrease in dissolved inorganic nitrogen forms, especially $\mathrm{NH}_{4}^{+}$, has been detected in the water column between 1987 and 2003 (Aubriot et al., 2005). In fact, concentrations have ranged from $14 \mu \mathrm{M}$ to undetectable levels $(<0.1 \mu \mathrm{M})$ over time and there is apparently no clear temporal trend in the observed concentrations (Calliari et al., 2009). The inorganic nitrogen depletion in this system could be attributed to a nitrification-denitrification coupling taking place at the sediment level. Another plausible explanation that was tested in the present study would be that the interaction between bacterioplankton and phytoplankton favors the rapid uptake of $\mathrm{NH}_{4}^{+}$that enters Laguna de Rocha. In order to test it, an experimental approach involving microcosms incubations amended with stable isotope-labelled $\mathrm{NH}_{4}^{+}$and size fractionation was attempted.

\section{METHODS}

\section{Study site}

Laguna de Rocha $\left(34^{\circ} 33 \mathrm{~S}^{\prime}, 54^{\circ} 22^{\prime} \mathrm{W}\right)$ is a coastal lagoon located on a microtidal coast, which periodically connects with the Atlantic Ocean through a narrow channel that opens on the sand bar (choked-type lagoon). It has a mean depth of $0.6 \mathrm{~m}$ and an area of $72 \mathrm{~km}^{2}$. When the sand barrier opens as a consequence of SE winds or by human action, the marine intrusion gradually divides the lagoon into a brackish water zone (South) having low nutrient concentration and high photosynthetically active radiation and UV penetration, and a freshwater zone (North) with high nutrient concentration, high turbidity and low solar radiation penetration. Laguna de Rocha has been extensively studied and further details can be found in Conde et al. (2000), Conde et al. (2002), Bonilla et al. (2005), Piccini et al. (2006), and Piccini et al. (2009).

\section{Sampling and in situ measurements}

Samples were taken from two sites corresponding to the above-described freshwater and brackish water zones of the lagoon (Conde et al., 2000) in the Austral autumn (May 2009). On each sampling site, $\mathrm{pH}$, temperature and conductivity were measured with a portable meter (ESI2, Horiba Inc., Irvine, CA, USA). Analysis of dissolved inorganic $\mathrm{N}$ (DIN: $\mathrm{NH}_{4}{ }^{+}, \mathrm{NO}_{3}{ }^{-}$and $\mathrm{NO}_{2}{ }^{-}$), total $\mathrm{N}$ and $\mathrm{P}$ (TN and TP respectively) were determined according to APHA (1995) and Valderrama (1981). To determine the source of DOM in each zone, the content of chromophoric dissolved organic matter (CDOM) was used as a proxy of allochthonous origin. Samples for CDOM measurements were filtered on the same day (within $6 \mathrm{~h}$ ) through $0.2 \mu \mathrm{m}$ polycarbonate filters (Millipore, Billerica, MA, USA), previously soaked overnight in $10 \% \mathrm{HCl}$ and rinsed with $20 \mathrm{~mL}$ of Milli-Q water. CDOM absorbance was measured at room temperature in a doublebeam spectrophotometer (Shimadzu UV1603) between 280 and $750 \mathrm{~nm}$ using acid-cleaned $5 \mathrm{~cm}$ fused silica cuvettes (Suprasil I) previously rinsed with Milli-Q water and twice with the filtered sample Milli-Q water of low dissolved organic carbon (DOC) concentration (0.05 $\mathrm{mg} . \mathrm{L}^{-1}$ ) was used as a reference. Absorption coefficients (a) were calculated as: $a=2.303 \mathrm{D} / \mathrm{l}$, where $D$ is absorbance and $l$ is the pathlength of the cuvette in meters. Correction for scattering caused by particles was done by subtracting the absorbance value at $690 \mathrm{~nm}$ (Kirk, 1994). For comparative purposes, we used the absorption value of CDOM at $355 \mathrm{~nm}\left(a_{355}\right)$. as a proxy to compare both studied areas (Pugnetti et al., 2010). The following equation was used to quantify the CDOM present:

$$
\operatorname{aCDOM}(355)=2.303 \mathrm{~A}_{\mathrm{CDOM}(335)} \cdot \mathrm{L}^{-1}
$$

Particulate organic carbon (POC) and nitrogen (PON) were analyzed after filtration through precombusted $\mathrm{GF} / \mathrm{C}$ filters $\left(4 \mathrm{~h}, 450^{\circ} \mathrm{C}\right) . \mathrm{POC}$ and PON concentrations were determined using a continuous-flow isotope ratio mass spectrometer (Finnigan Delta Plus EA-IRMS). To remove inorganic carbonates, samples were treated with fuming $\mathrm{HCl}$ before their analysis (Nieuwenhuize et al., 1994).

\section{Experimental setup}

In order to address the $\mathrm{NH}_{4}{ }^{+}$uptake of phytoplankton 
and bacterioplankton separately, a size-fractionation approach was used. Experiments were carried out in triplicate acid-cleaned PVC cylinders (microcosms) filled with $3 \mathrm{~L}$ of water taken from the brackish water zone (South) and the freshwater zone (North) (Conde et al., 2000). Each set of microcosm had two treatments, one consisted of unfiltered lagoon water (LW treatment, all plankton fractions) and the other consisted of water previously filtered through $1.2 \mu \mathrm{m}$ glass fiber filters (FW treatment, mainly bacterioplankton and virioplankton). Size fractionation was achieved by gentle vacuum filtration $(<125 \mathrm{~mm} \mathrm{Hg})$. Each microcosm was amended with $\left({ }^{15} \mathrm{NH}_{4}\right)_{2} \mathrm{SO}_{4}(99 \%$ at., Aldrich, St. Louis, MO, USA)) at a final concentration of $50 \mathrm{nmol} \mathrm{L}^{-1}$, which was used in order to be close to $10 \%$ of ambient concentration and avoid over enrichment (Conde et al., 2000; Aubriot et al., 2005). Incubations were run at the in situ temperature $\left(15^{\circ} \mathrm{C}\right)$ in a circulating water bath under PAR intensity of $689 \mu \mathrm{mol} \mathrm{m}^{-2} \mathrm{~s}^{-1}$ and subsamples were taken at $0,0.5,2$ and $4 \mathrm{~h}$. The short incubation times were chosen according to previous studies on site (Piccini et al., 2009; Alonso et al., 2013) considering the bacterial activity and its dynamics as well as to prevent the effect of confinement on bacterial growth as it has been reported (Fergusson et al., 1984; Fuchs et al., 2000). Water samples from LW treatment were size-fractioned post-incubation using $1.2 \mu \mathrm{m}$ glass fiber filters $(\mathrm{GF} / \mathrm{C}$ Whatman Inc., Florham Park, NJ, USA) to retain most of the phytoplankton community (phytoplankton-enriched fraction, PHYTO) (Bonilla et al., 2005; Vidal et al., 2007); the resulting filtrate was passed through $0.5 \mu \mathrm{m}$ glass fiber filters (GE Water \& Process Technologies, Boulder, CO, USA) to get the bacterioplankton community (bacteria-enriched fraction, BACT). In case of the FW treatment, water samples from the microcosms were directly filtered through $0.5 \mu \mathrm{m}$ glass fiber filters (BACT fraction). All glass-fiber filters were combusted $\left(4 \mathrm{~h}\right.$ at $\left.450^{\circ} \mathrm{C}\right)$ prior to use. In order to check that all the biomass was retained after filtrating through the $0.5 \mu \mathrm{m}$ glass fibre filters, portions of $3 \mathrm{~mL}$ of water from the FW were filtered through polycarbonate filters (type GTTP, $0.2 \mu \mathrm{m}$ pore size, $47 \mathrm{~mm}$, Millipore) and checked by epifluorescence microscopy to see the presence any cell. In parallel fluorescence of $\mathrm{Ch}$ a in vivo was also checked. In both cases, no cells nor Chl $a$ fluorescence were detected suggesting that all the biomass was retained in the filter.

\section{Ammonium uptake rates}

Filters containing particulate organic matter were dried at $60^{\circ} \mathrm{C}$ and placed into $10 \times 10 \mathrm{~mm}$ tin cups (Santis, Switzerland) before analysis using a continuous-flow isotope ratio mass spectrometer (Finnigan Delta Pluss EAIRMS). Absolute $\mathrm{NH}_{4}{ }^{+}$uptake rates ( $\rho \mathrm{N}: \mathrm{nmol} \mathrm{L}^{-1} \mathrm{~h}^{-1}$ ) representing the amount of $\mathrm{N}$ as $\mathrm{NH}_{4}{ }^{+}$taken up during the incubation time standardized per $\mathrm{h}$ were calculated using the following equation (Dugdale and Wilkerson, 1986):

$$
\rho \mathrm{NH}_{4}^{+}=\frac{R_{P O N}}{R_{\mathrm{NH}_{4}^{+}} \times t} \times[\mathrm{PON}]
$$

where $\mathrm{R}_{\mathrm{PON}}$ and $\mathrm{R}_{\mathrm{NH} 4+}$ represent the ${ }^{15} \mathrm{~N}$ atom percent enrichment in the $\mathrm{PON}$ and $\mathrm{NH}_{4}{ }^{+}$pools, and [PON] represents the final PON concentration; $t$ represents the duration (h) of the incubation. Absolute uptake rates were not corrected by the isotopic dilution effect (Glibert et al., 1982).

Turnover times of $\mathrm{NH}_{4}{ }^{+}$for each fraction were calculated by dividing the ambient concentration of $\mathrm{NH}_{4}{ }^{+}$by the corresponding uptake rate.

\section{Bacterial abundance and phytoplankton biomass}

Water samples to determine bacterial abundance from both treatments were taken at the time intervals mentioned and immediately fixed with freshly prepared buffered paraformaldehyde solution (PFA) at a final concentration of $1 \%$ for $24 \mathrm{~h}$. Afterwards filters were rinsed twice with sterile phosphate buffered saline (PBS) and stored at $-20^{\circ} \mathrm{C}$ until further analysis.Bacterial abundance was determined by staining cells with a final concentration of $1 \mu \mathrm{g} . \mathrm{mL}^{-1}$ of 4',6-diamidino-2-phenylindole (DAPI) (Porter and Feig, 1980). DAPI-stained cells were counted manually achieving a minimum of 1000 cells per filter assisted by the free counting software ClickCounter (http://www.biotechnobiology.ch). Phytoplankton biomass was estimated by measuring the in vivo Chl $a$ fluorescence (Aquafluor Turner Designs, USA) (Briand et al., 2004; Alonso et al., 2013). The phytoplankton taxa were not assessed in this study.

\section{Statistical analyses}

In order to determine if the detected differences between uptake rates, bacterial abundance and in vivo $\mathrm{Chl} a$ fluorescence were significant, repeated measures analyses of variance (rmANOVA) tests were performed using Statistica (v.7) (P-values of 0.05 were considered as the significant threshold). Statistical relationships among the variables were tested with non-parametric Spearman rank correlations (r). The significance of the differences between variables was estimated with the Mann-Whitney test (MW) using Statistica 7.0 (StatSoft).

\section{RESULTS}

\section{Environmental parameters of the sampling sites}

At the time of the experiments, the lagoon was connected to the ocean. Thus, the average conductivity in the South zone was higher than in the North ( 42.9 and $24.7 \mathrm{mS}$ $\mathrm{cm}^{-1}$, respectively). DIN forms $\left(\mathrm{NH}_{4}^{+}, \mathrm{NO}_{3}{ }^{-}\right.$and $\left.\mathrm{NO}_{2}{ }^{-}\right)$ were all undetectable in the South, whereas in the North the concentration of $\mathrm{NH}_{4}{ }^{+}$and $\mathrm{NO}_{3}{ }^{-}$were 0.18 and 3.04 $\mu \mathrm{mol} \mathrm{L}{ }^{-1}$ respectively. $\mathrm{NO}_{2}^{-}$, on the other hand, was un- 
detactable. Total nitrogen concentration in the North freshwater zone $\left(11.8 \mu \mathrm{mol} . \mathrm{L}^{-1}\right)$ was, on average, almost twice than in the South $\left(7.1 \mu \mathrm{mol} . \mathrm{L}^{-1}\right)$, but total phosphorus was similar between sites (1.8 and $2.2 \mu \mathrm{M}$ in North and South, respectively). POC values were significantly higher in the North $\left(181.8\right.$ vs $\left.100.6 \mu \mathrm{mol}^{-\mathrm{L}^{-1}} ; \mathrm{P}<0.05\right)$ and no differences in PON concentration between sites were found (5.3 and $5.2 \mu \mathrm{mol} . \mathrm{L}^{-1}$ in North and South, respectively). When $\mathrm{C}: \mathrm{N}$ ratios were calculated from POC and PON, the ratios found in the North (34.2) were higher than in the South (19.4). Also, the amount of CDOM measured as $a_{355} \mathrm{~nm}$ was higher in the freshwater zone $\left(2.67 \mathrm{~m}^{-1} v \mathrm{~s}\right.$ $0.23 \mathrm{~m}^{-1}$ in the South).

\section{Bacterial and phytoplankton ammonium uptake rates}

The ammonium uptake rates observed for each assessed planktonic fraction were significantly different between experiments from both zones of Laguna de Rocha. In the North LW treatment incubations, $\mathrm{NH}^{+}$was actively and similarly assimilated by the bacterial and phytoplankton fractions $(\mathrm{P}>0.05)$ (Fig. 1A). However, in the FW (prefiltered water) treatment, bacterial $\mathrm{\rho NH}_{4}{ }^{+}$was significantly lower than its counterpart from the LW treatment (almost 10-fold; $\mathrm{P}<0.05$ ) (Fig. 1C). On the other hand, $\mathrm{NH}_{4}^{+}$uptake rates calculated for both microbial fractions in the South LW treatment were remarkably lower than those reached in the North $(\mathrm{P}<0.05)$. In this experiment, the phytoplankton fraction showed significantly higher ammonium uptake rates $\left(2.60 \pm 0.64 \mathrm{nmol} \mathrm{N} \mathrm{L}{ }^{-1} \mathrm{~h}^{-1}, \mathrm{P}<0.05\right)$ than the bacterial fraction only at the end of LW incubations (Fig. 1B). When incubated alone (FW treatment) bacteria showed lower ammonium uptake rates than in the LW treatment, although this difference was not significant $(\mathrm{P}>0.05)$ (Fig. 1D). Both bacterioplankton and phytoplankton fractions showed a positive and significant correlation in their $\mathrm{NH}_{4}^{+}$uptake process in the North $\left(\mathrm{r}^{2}=0.8263 ; \mathrm{P}<0.05\right)$, whereas in the South this correlation was weaker $\left(\mathrm{r}^{2}=0.2601 ; \mathrm{P}<0.05\right)$ but significant. On the other hand, no significant correlation between the bacterial abundance and $\mathrm{NH}_{4}^{+}$uptake or with in vivo fluorescence
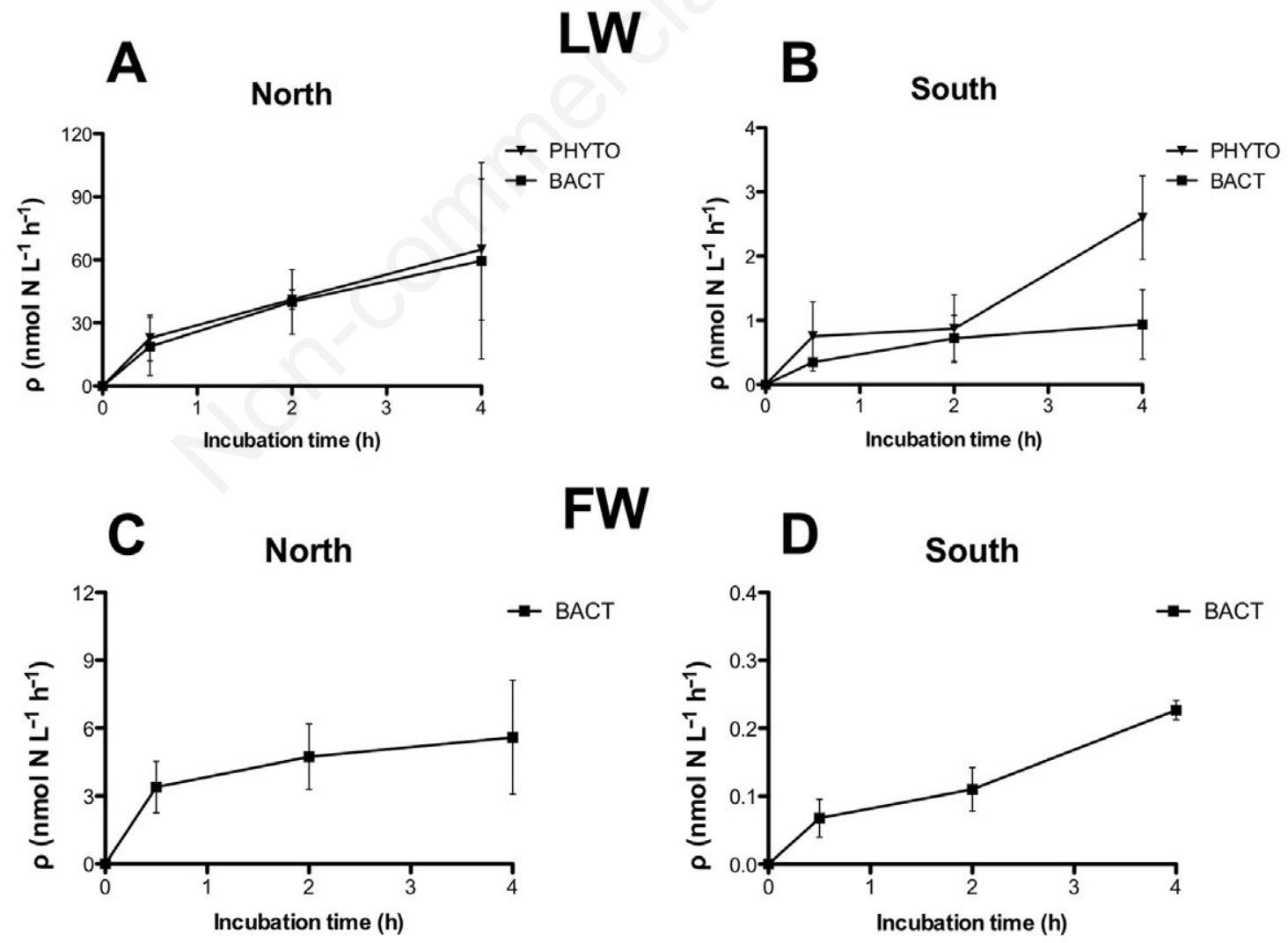

Fig. 1. Uptake rates of ammonium $\left(\mathrm{\rho NH}_{4}^{+}\right)$, expressed in nmol N. $\mathrm{L}^{-1} \cdot \mathrm{h}^{-1}$ for phytoplankton and bacterioplankton communities for both zones (North and South) of Laguna de Rocha. A and B, uptake rates of phytoplankton and bacterioplankton from whole lagoon water treatment (LW) found in the North and in the South, respectively. C and D, uptake rates calculated for BACT from the pre-filtered water treatment (FW) in the North and South, respectively. 
of Chla was found (data not shown). Isotopic dilution of ${ }^{15} \mathrm{NH}_{4}^{+}$due to bacterial regeneration process can potentially lead to an underestimation of the uptake rates (Glibert et al., 1982). Although no $\mathrm{NH}_{4}^{+}$regeneration experiments were conducted in this study, the higher $\mathrm{NH}_{4}^{+}$concentration in the North may indicate that this process could have been more prevalent than in the South.

Ammonium turnover times calculated for each microbial fraction were similar in the LW North treatment $(0.10$ and $0.12 \mathrm{~d}$ for phytoplankton and bacterioplankton fractions respectively). Since ambient $\mathrm{NH}_{4}^{+}$concentration in the South was below detection limit, turnover times for each microbial fraction were not possible to be calculated.

\section{Bacterioplankton and phytoplankton dynamics during incubations}

The abundance of bacteria in the North LW treatment showed a significant decrease towards the end of the incubation $(\mathrm{P}<0.05)$, while in the South bacterial abundance slightly increased (Fig. 2A). On the other hand, in the pre-filtered treatments (FW) from both zones bacterial numbers remained fairly constant through incubation time, showing no significant differences between the beginning and the end of the incubations ( $\mathrm{P}>0.05)$ (Fig. 2B).

Phytoplankton biomass in LW treatments showed no significant differences during the time of incubation for any zone $(\mathrm{P}>0.05)$. However, there were significant differences in the biomass of primary producers between zones $(\mathrm{P}<0.05)$ (Fig. 2C). The observation of the $0.2 \mu \mathrm{m}$ polycarbonate filters revealed the presence of unicellular phytoplankters in the LW treatment in both studied zones of the lagoon. However, in the FW treatment the recorded fluorescence values were negligible, and no autofluorescent cells at the epifluorescence microscope were detected (data not shown).
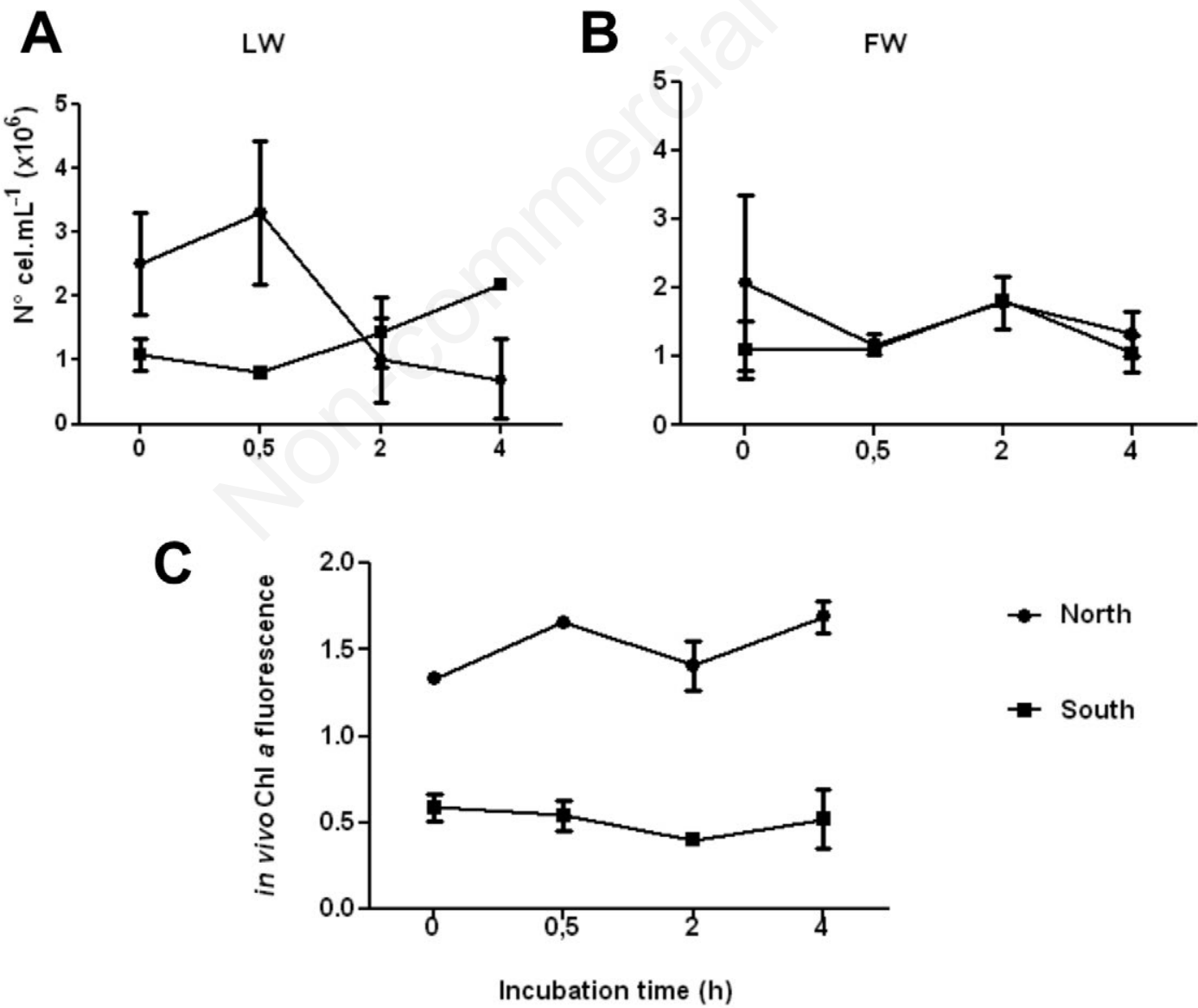

Fig. 2. Bacterial abundance found in the experiments performed in the North and South sampling sites of Laguna de Rocha. A) Bacterial counts in the whole lagoon water treatment (LW). B) Bacterial counts from the pre-filtered water treatment (FW). C) In vivo fluorescence of Chl a measured in this experiment (in relative fluorescence units). 


\section{DISCUSSION}

In this study we analyzed the ammonium uptake rates of phytoplankton and bacterioplankton in a brackish coastal lagoon by a size fractionation approach in order to address the interactions between them in distinct environmental compartments of the system. The first outcome of our study was that ammonium uptake by bacterioplankton was enhanced by the presence of phytoplankton in the incubations, being this trend more clear in the experiments using water from the Northern zone of the lagoon (freshwater influence). This finding may suggest that during experiments, bacterioplankton obtained the nitrogen (and probably carbon and other nutrients) from phytoplankton exudates and that this coupling was very fast $(4 \mathrm{~h})$. According to the current conceptual models, we expected that in this zone of the lagoon the coupling between bacterioplankton and phytoplankton would be less tight, owing to higher concentrations of organic matter and nutrients to sustain bacterial growth (Fouilland and Mostajir, 2010). Also, it has been recently shown that lake bacterioplankton can growth on allocthonous DOM (Guillemete and del Giorgio, 2012). However, in this study this may not have been the case. As it has been previously described for this ecosystem, nutrients and DOM concentrations are usually higher in the North zone, although DOM is not always in a bioavailable form (Conde et al., 2002; Piccini et al., 2009; Alonso et al., 2013). In the present study, the North zone also showed a higher concentration of inorganic nitrogen forms and a high C:N ratio, suggesting that although nitrogen was available a great portion of DOM carbon could have not been available for bacterial growth, since it was mainly plant or macrophytederived (allochtonous origin). This was supported by $a_{355}$ indexes that were consistent with those generally observed near the mouth of large rivers (Blough and Del Vecchio, 2002). The presence of allochtonous, less labile DOM in this zone of the lagoon, has also been confirmed previously by Piccini et al. (2009), who showed that photodegradation increased the availability of DOM, stimulating the rapid growth and activity of bacterioplankton. Therefore, it is very likely that under certain hydrological conditions (e.g., riverine inputs) bacterioplankton growth in the freshwater compartment strongly depends on phytoplankton exudates as a source of nutrients, especially organic carbon. The positive and significant correlations found between bacterioplankton and phytoplankton $\mathrm{NH}_{4}{ }^{+}$ uptake rates support this finding, suggesting that this process was coupled between these communities in the North of Laguna de Rocha. Coupling in the ammonium uptake by phytoplankton and bacterioplankton has also been reported in other estuarine environments as the Delaware estuary (Parker, 2005) or coastal waters (Bradley et al., 2010).

Turnover times based on ${ }^{15} \mathrm{~N}$-tracer experiments re- flect the dynamics of $\mathrm{N}$ assimilation process in aquatic systems. When compared with the water residence time, it gives information whether nutrients are exported to the sea or recycled within the system (Middelburg and Nieuwenhuize, 2000). In this study, both fractions showed similar turnover times in the North $(\approx 0.12 \mathrm{~d})$. Since the water residence time can reach 30 days (closed condition) at Laguna de Rocha, it can be assumed that both communities quickly recycle $\mathrm{NH}_{4}^{+}$through uptake and assimilation. This is particularly important since it shows that bacterioplankton play an active role in the $\mathrm{NH}_{4}{ }^{+}$uptake. Furthermore, as bacterial nitrogen assimilation takes place, it lowers the $\mathrm{C}: \mathrm{N}$ ratio and enhances the nutritional value of particulate matter, which is an important food source for pelagic and benthic consumers (Middelburg and Nieuwenhuize, 2000). On the other hand, turnover times in the South area of the lagoon could not be calculated because $\mathrm{NH}_{4}^{+}$ambient concentration was below the detection limit $\left(<0.1 \mu \mathrm{mol} . \mathrm{L}^{-1}\right)$. Under the physicochemical conditions of the South brackish zone, bacterioplankton $\mathrm{NH}_{4}^{+}$uptake was less dependent on phytoplankton, since uptake rates measured in the pre-filtered treatment were similar to those found in the unfiltered water. This suggests a weaker coupling between these two communities in the $\mathrm{NH}_{4}^{+}$uptake. Several studies on European estuaries have shown that $\mathrm{N}$ uptake rates are lower when reaching the more saline gradient of the estuary (Middelburg and Nieuwenhuize, 2000; Veuger et al., 2004). These authors found that near the mouth of estuaries, dissolved free aminoacids (DFAA) had an important contribution to the microbial $\mathrm{N}$ demand and that the community preferred this form of $\mathrm{N}$. This may explain why the $\mathrm{NH}_{4}^{+}$uptake rates in the South were lower than in the North and may suggest that another $\mathrm{N}$ form fulfils the requirements of the planktonic community in this zone of Laguna de Rocha.

Regarding other estuarine systems, bacterial ammonium uptake rates found in the North LW treatment are similar to those found in the Delaware Estuary using the same experimental approach (Parker, 2005) and those reported in a Mediterranean coastal lagoon using eukaryotic inhibitors (Trottet et al., 2011). It has been described that when substrate enrichments are below $50 \%$ of the nutrient in situ concentration, uptake rates must be regarded as real. On the contrary, when enrichments are above this value, uptake rates have to be considered as potential (Fernandez et al., 2005). In the experiment performed in the freshwater zone, we found that substrate enrichment after tracer addition was $36 \%$, leading to real uptake measures. In the case of the South LW treatment enrichment was close to $100 \%$, since $\mathrm{NH}_{4}^{+}$was undetectable, meaning that rates have to be considered as potential.

According to our results, the interaction between phytoplankton and bacterioplankton, as well as the environmental conditions in each compartment, would be the 
main factors influencing the bacterial uptake of $\mathrm{NH}_{4}{ }^{+}$in Laguna de Rocha. Besides, these results highlight the differential relevance of these two components of the microbial loop components in the nitrogen uptake. It should be noticed that either predation or viral lysis could have also controlled bacterial abundance (top-down control) in the North experiments. This has already been observed and studied in this system (Alonso et al., 2013) and has been postulated as a resilience mechanism (Piccini et al., 2006). However, top-down control might have not affected the $\mathrm{NH}_{4}{ }^{+}$uptake process, suggesting that a selective predation on less active bacterial groups could have occurred or, as explained above, that the uptake process was not associated with the bacterial biomass.

Previous studies in Laguna de Rocha indicate that primary producers are mainly structured by the spatial environmental variability, which is a consequence of the hydrology of the ecosystem (Conde et al., 1999). Analyses of phytoplankton in this system have shown that biomass values are in the range of other mesoeutrophic and eutrophic lagoon ecosystems of the region (Abreu et al., 1994), and that the community assemblage composition is mainly composed by diatoms and flagellates of different groups (Conde et al., 1999; Bonilla et al., 2005; Vidal et al., 2007). In our study, the presence of unicellular picophytoplanktonic organisms in both zones of the lagoon was detected. Autotrophic picophytoplankton ( 0.7 to $3 \mu \mathrm{m}$ size) is an important fraction of the total phytoplankton biomass in Laguna de Rocha, and its contribution to total phytoplankton biomass was found to be higher under conditions of nitrogen limitation (Vidal et al., 2007). Also, the physical conditions found in the lagoon when performing our experiments would select unicellular planktonic species, according to previous findings by Bonilla et al. (2005). As it was expected, Chl $a$ in vivo fluorescence measured in the pre-filtered treatments was under the detection limit in both zones, indicating that the experimental approach used was useful to split both communities and that calculated uptake rates of $\mathrm{NH}_{4}^{+}$ corresponded effectively to the previously assigned communities.

\section{CONCLUSIONS}

Overall, the results obtained in this work showed that bacterioplankton has an active role in the ammonium uptake in Laguna de Rocha. It is worth noting the dependence of the bacterial ammonium uptake on phytoplankton which led to a tight coupling between both communities in the uptake process in the freshwater zone. Even though higher DOM and nutrient concentrations are usually found there (Conde et al., 2002; Piccini et al., 2009), bacterioplankton probably supported its ammonium uptake on phytoplankton DOM. This could be because the allochthonous DOM in this system in this particular situation was not readily labile for bacterioplankton. Therefore, the interactions between both communities, as well as environmental conditions at each compartment caused by the complex hydrology would be the main factors influencing the uptake of ammonium in this coastal lagoon.

\section{ACKNOWLEDGMENTS}

We thank M. Gallegos and M.E. Alcamán (PROFC) for technical advice and help during sample analysis, C. Kruk for helping during statistical analysis and R. Sommaruga for his critical review of the manuscript. This work was supported by the Programa de Desarrollo de las Ciencias Básicas (PEDECIBA), Agencia Nacional de Investigación y Ciencia (ANII), the AMSUD-Pasteur Program and the LIA MORFUN (LF and CF).

\section{REFERENCES}

Abreu P, Odebrecht C, Gonzalez, P, 1994. Particulate and dissolved phytoplankton production of the Patos lagoon estuary, southern Brazil: comparison of methods and influencing factors. J. Plankton Res. 16:737-735.

Alonso C, Gómez-Pereira P, Ramette A, Ortega L, Fuchs B, Amann R, 2010. Multilevel analysis of the bacterial diversity along the environmental gradient Río de la Plata-South Atlantic Ocean. Aquat. Microb. Ecol. 61:57-72.

Alonso C, Piccini C, Unrein F, Bertoglio F, Conde D, Pernthaler J, 2013. Environmental dynamics as a structuring factor for microbial carbon utilization in a subtropical coastal lagoon. Front. Aquat. Microbiol. 4:14.

APHA, 1995. Standard methods for the examination of water and wastewater. APHA/AWWA/WPFC. Washington: $1268 \mathrm{pp}$.

Aubriot L, Conde D, Bonilla S, Britos A, 2005. [Evolución histórica de la carga de nutrientes asociada a cambios en el estado trófico actual]. In: Conde, Rodríguez, Fagetti, Vintacourt (eds.), [Avances científico-técnicos para el manejo del área protegida Laguna de Rocha]. [Book in Spanish]. Montevideo, Uruguay.

Berman T, Chava S, 1999. Algal growth on organic compounds as nitrogen sources. J. Plankton Res. 21:1423-1437.

Björkman KM, Karl DM, 1994. Bioavailability of inorganic andorganic phosphorus compounds to natural assemblages of microorganisms in Hawaiian coastal waters. Mar. Ecol. Prog. Ser. 111:265-273.

Blomqvist P, Petterson A, Hyenstrand P, 1994. Ammonium-nitrogen - a key regulatory factor causing dominance of nonnitrogen-fixing cyanobacteria in aquatic systems. Arch. Hydrobiol. 132:141-164.

Blough NV, Del Vecchio R, 2002. Chromophoric DOM in the coastal environment, p. 509-578. In: D.A. Hansell and C.A. Carslon (eds.), Biogeochemistry of marine dissolved organic matter. Academic Press, San Diego.

Bonilla S, Conde D, Aubriot L, Pérez MC, 2005. Influence of hydrology and nutrients on phytoplankton species composition and life strategies in a subtropical coastal lagoon. Estuaries 28:884-895. 
Bouvier TC, del Giorgio PA, 2002. Compositional changes in free-living bacterial communities along a salinity gradient in two temperate estuaries. Limnol. Oceanogr. 2:453-470.

Bradley PB, Sanderson MP, Nejstgaard JC, Sazhin AF, Frischer ME, Killberg-Thoreson, LM, Verity PG, Campbell L, Bronk, DA, 2010. Nitrogen uptake by phytoplankton and bacteria during an induced Phaeocystis pouchetii bloom, measured using size fractionation and flow cytometric sorting approaches. Aquat. Microb. Ecol. 61:89-104.

Briand JF, Leboulanger C, Humbert JL, 2004. Cylindrospermopsis raciborskii (Cyanobacteria) invasion at mid-latitudes: selection, wide physiological tolerance or global warming. J. Phycol. 40:231-238.

Brock TD, Madigan MT, Martinko JM, Parker J, 1994. Biology of microorganisms, $7^{\text {th }}$ ed. Prentice Hall: 909 pp.

Calliari D, Britos A, Conde D, 2009. Testing the relationship between primary production and Acartia tonsa grazing pressure in an estuarine lagoon. J. Plankton Res. 31:104510581.

Cole JJ, Findlay S, Pace ML, 1988. Bacterial production in fresh and saltwater ecosystems: a cross-system overview. Mar. Ecol. Progr. Ser. 43:1-10.

Conde D, Bonilla S, Aubriot L, De León R, Pintos W, 1999. Comparison of the areal amount of chlorophyll a of planktonic and attached microalgae in a shallow coastal lagoon. Hydrobiologia 408/409:285-291.

Conde D, Aubriot L, Sommaruga R, 2000. Changes in UV penetration associated with marine intrusions and freshwater discharge in a shallow coastal lagoon of the Southern Atlantic Ocean. Mar. Ecol. Progr. Ser. 207:19-31.

Conde D, Aubriot L, Bonilla S, Sommaruga R, 2002. Marine intrusions in a coastal lagoon enhances the effects of UV radiation on the phytoplankton photosynthetic rate. Mar. Ecol. Progr. Ser. 240:57-70.

Dugdale RC, Wilkerson FP, 1986. The use of ${ }^{15} \mathrm{~N}$ to measure nitrogen uptake in eutrophic oceans, experimental considerations. Limnol. Oceanogr. 31:673-689.

Fernández C, Raimbault P, Garcia N, Rimmelin P, Caniaux G, 2005. An estimation of annual new production and carbon fluxes in the northeast Atlantic Ocean during 2001. J. Geophys. Res. 110:CO7513.

Ferguson R, Buckley EN, Palumbo AV, 1984. Response of marine bacterioplankton to differential filtration and confinement. Appl. Environ. Microbiol. 47:49-55.

Finlay K, Leavitt PR, Patoine A, Wissel B, 2010. Magnitudes and controls of organic and inorganic carbon flux through a chain of hardwater lakes on the northern Great Plains. Limnol. Oceanogr. 55:1551-1564.

Fouilland E, Mostajir B, 2010. Revisited phytoplanktonic carbon dependency of heterotrophic bacteria in freshwaters, transitional, coastal and oceanic waters. FEMS Microbiol. Ecol. 73:419-429.

Glibert PM, Lipschultz F, McCarthy JJ, Altabet, M, 1982. Isotope dilution models of uptake and remineralization of ammonium by marine plankton. Limnol. Oceanogr. 36:895-909.

Glöckner FO, Fuchs BM, Amann R, 1999. Bacterioplankton compositions of lakes and oceans: a first comparison based on fluorescence in situ hybridization. Appl. Environ. Microbiol. 65:3721-3726.

Goldman JC, Dennet, MR, 2000. Growth of marine bacteria in batch and continuous culture under carbon and nitrogen limitation. Limnol. Oceanogr. 45:789-800.

Gomez-Pereira PR, Fuchs BM, Alonso C, Oliver MJ, van Beusekom JEE, Amann R, 2010. Distinct flavobacterial communities in contrasting water masses of the North Atlantic Ocean. ISME J. 4:472-487.

Guillemette F, del Giorgio PA, 2012. Simultaneous consumption and production of fluorescent dissolved organic matter by lake bacterioplankton. Environ. Microbiol. 14:1432-1443.

Havskum H, Thingstad TT, Scharek R, Peters F, Berdalet E, Sala MM, Alcaraz M, Bangsholt JC, Zweifel UI, Hagström A, Perez M, Dolan JR, 2003. Silicate and labile DOC interfere in structuring the microbial food web via algal-bacterial competition for mineral nutrients: Results of a mesocosm experiment. Limnol. Oceanogr. 48:129-140.

Hopkinson CSJ, Smith EM, 2005. Estuarine respiration: an overview of benthic, pelagic and whole system respiration, $\mathrm{p}$. 123-147. In: P.A. del Giorgio and L.P.J. Williams (eds.), Respiration in aquatic ecosystems. Oxford University Press, UK.

Joint I, Henriksen P, Fonnes GA, Bourne D, Thingstad TF, Riemman B, 2002. Competition for inorganic nutrients between phytoplankton and bacterioplankton in nutrient manipulated mesocosms. Aquat. Microbiol. Ecol. 29:145-159.

Kent AD, Smith DJ, Benson BJ, Triplett EW, 2003. Web-based phylogenetic assignment tool for analysis of terminal restriction fragment length polymorphism profiles of microbial communities. Appl. Environ. Microbiol. 69:6768-6776.

Kirchman DL, Dittel, AI, Malmstrom RR, Cottrell MT, 2005. Biogeography of major bacterial groups in the Delaware Estuary. Limnol. Oceanogr. 5:1697-1706.

Kirk JTO, 1994. Optics of UV-B radiation in natural waters. Ergeb. Limnol. 43:1-16.

Lind OT, Chrzanowski TH, Dávalos-Lind L, 1997. Clay turbidity and the relative production of bacterioplankton and phytoplankton. Hydrobiologia 353:1-18.

Middelburg JL, Nieuwenhuize J, 2000. Nitrogen uptake by heterotrophic bacteria and phytoplankton in the nitrate-rich Thames estuary. Mar. Ecol. Progr. Ser. 203:13-21.

Nieuwenhuize J, Maas YEM, Middelburg JJ. 1994. Rapid analysis of organic carbon and nitrogen in particulate materials. Mar. Chem. 45:217-224.

Parker AE, 2005. Differential Supply of Autochthonous Organic Carbon and Nitrogen to the Microbial Loop in the Delaware Estuary. Estuaries 28:856-867.

Piccini C, Conde D, Alonso C, Sommaruga R, Pernthaler J, 2006 Blooms of single bacterial species in a coastal lagoon of the Southwestern Atlantic Ocean. Appl. Environ. Microbiol. 72:6560-6568.

Piccini C, Conde D, Pernthaler J, Sommaruga R, 2009. Alteration of chromophoric dissolved organic matter by solar UV radiation causes rapid changes in bacterial community composition. Photochem. Photobiol. Sci. 8:1321-1328.

Pomeroy LR, 1974. The ocean's food web, a changing paradigm. BioScience 24:499-504.

Porter KG, Feig YS, 1980. The use of DAPI for identifying and counting aquatic microflora. Limnol. Oceanogr. 25:943-948.

Pugnetti A, Del Negro P, Giani M, Acri F, Aubry FB, Bianchi F, Berto D, Valeri A, 2010. Phytoplankton-bacterioplankton interactions and carbon fluxes through microbial communities in a microtidal lagoon. FEMS Microbiol. Ecol. 2:153-164. 
Revilla M, Aristeguı A, Iriarte A, Madariaga I, Orive E, Sarobe A, Trigueros JM, 2002. Microplankton metabolism along a trophic gradient in a shallow-temperate estuary. Estuaries 25:6-18

Thompson FL, Rodrigues TB, Gonzalez A, Cardoso A, Clementino M, Costagliola M, Edwards R, Hozbor C, Otero E, Paranhos R, Piccini C, Peressutti S, Schneider R, Smith M, Takiyama LR, Vieira R, Artigas LF, 2011. Coastal bacterioplankton community diversity along a latitudinal gradient in Latin America by means of pyrosequencing. Arch. Microbiol. 193:105-114.

Trottet A, Fouilland E, Leboulanger C, Lanouguère E, Bouvy M, 2011. Use of inhibitors for coastal bacteria and phyto- plankton: application to nitrogen uptake rates. Estuar. Coast. Shelf Sci. 93:151-159.

Valderrama JC, 1981. The simultaneous analysis of total nitrogen and total phosphorus in natural waters. Mar. Chem. 10:109-122.

Vidal L, Rodríguez-Gallego L, Conde D, Martínez-López W, Bonilla S, 2007. Biomass of autotrophic picoplankton in subtropical coastal lagoons: is it relevant? Limnetica 26:441-452.

Veuger B, Middelburg JJ, Boschker HTS, Nieuwenhuize J, van Rijswijk P, Rochelle-Nevall EJ, Navarro N, 2004. Microbial uptake of dissolved organic and inorganic nitrogen in Randers Fjord. Estuar. Coast. Shelf Sci. 3:507-515. 